\title{
Ex vivo Retrieval of Mature Oocytes for Fertility Preservation in a Patient with Bilateral Borderline Ovarian Tumor
}

\section{Recuperação ex vivo de oócitos maduros para preservação da fertilidade em paciente com tumor ovariano borderline bilateral}

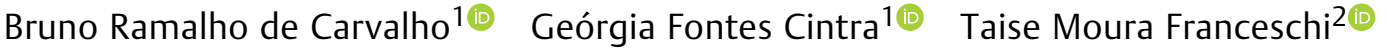 \\ Íris de Oliveira Cabral ${ }^{2(0)}$ Leandro Santos de Araújo Resende ${ }^{1(0)}$ Brenda Pires Gumz ${ }^{10}$ \\ Thiago David Alves Pinto ${ }^{3}$
}

\author{
${ }^{1}$ Hospital Sírio-Libanês, Brasília, DF, Brazil \\ 2 Genesis, Centro de Assistência em Reprodução Humana, Brasília, DF, Brazil \\ 3 Diagnose, Laboratório de Anatomia Patológica e Citologia, Brasília, \\ DF, Brazil
}

Address for correspondence Bruno Ramalho de Carvalho, SGAS 614, Conjunto C, Sala 177, Edifício VITRIUM - Centro Médico Inteligente, Asa Sul, Brasília, Distrito Federal, 70200-740, Brazil

(e-mail: ramalho.b@gmail.com).

Rev Bras Ginecol Obstet 2021;43(3):225-231.

\section{Abstract}

\section{Keywords}

- cryopreservation

- ex vivo oocyte retrieval

- fertility preservation

- ovarian cancer

- borderline ovarian tumor

- vitrification

\section{Resumo}

Palavras-chave

- criopreservação

- recuperação extracorpórea de oócitos

- preservação de fertilidade

- câncer do ovário

- tumor borderline de ovário

- vitrificação
We report a case of ultrasound-guided ex vivo oocyte retrieval for fertility preservation in a woman with bilateral borderline ovarian tumor, for whom conventional transvaginal oocyte retrieval was deemed unsafe because of the increased risk of malignant cell spillage. Ovarian stimulation with gonadotropins was performed. Surgery was scheduled according to the ovarian response to exogenous gonadotropic stimulation; oophorectomized specimens were obtained by laparoscopy, and oocyte retrieval was performed $\sim 37$ hours after the ovulatory trigger. The sum of 20 ovarian follicles were aspirated, and 16 oocytes were obtained. We performed vitrification of 12 metaphase II oocytes and 3 oocytes matured in vitro. Our result emphasizes the viability of ex vivo mature oocyte retrieval after controlled ovarian stimulation for those with high risk of malignant dissemination by conventional approach.

Relatamos um caso de obtenção ex vivo de óvulos, guiada por ultrassonografia, para preservação da fertilidade em uma mulher com tumor ovariano borderline bilateral, para quem a recuperação transvaginal convencional foi considerada insegura, devido ao aumento do risco de disseminação de células malignas. Foi realizada estimulação ovariana com gonadotrofinas. A cirurgia foi agendada de acordo com a resposta ovariana à estimulação gonadotrófica exógena; após ooforectomia por laparoscopia, $\sim 37$ horas após a maturação folicular, procedeu-se à recuperação extracorpórea de oócitos. Um total de 20 folículos ovarianos foi aspirado e 16 complexos cumulus foram obtidos, resultando na vitrificação de 12 oócitos maduros e de 3 oócitos imaturos amadurecidos in vitro. Nosso resultado enfatiza a viabilidade da recuperação ex vivo de oócitos maduros após estimulação ovariana controlada para mulheres com alto risco de disseminação maligna pela captação oocitária realizada convencionalmente pela via transvaginal. received

June 10, 2020

accepted

August 3, 2020

published online

January 19, 2021
DOI https://doi.org/

10.1055/s-0040-1718436. ISSN $0100-7203$. (c) 2021. Federação Brasileira de Ginecologia e Obstetrícia. All rights reserved.

This is an open access article published by Thieme under the terms of the Creative Commons Attribution License, permitting unrestricted use, distribution, and reproduction so long as the original work is properly cited. (https://creativecommons.org/licenses/by/4.0/)

Thieme Revinter Publicações Ltda., Rua do Matoso 170, Rio de Janeiro, RJ, CEP 20270-135, Brazil 


\section{Introduction}

According to the literature, the incidence of borderline ovarian tumors (BOTs) in women $<45$ years old varies between 27 and 59\%. ${ }^{1-3}$ Indeed, the expected good prognosis of BOT and the current trends of having a first baby after 30 years old lead to the fact that more women presenting with the tumor should not have started their offspring yet at the time of diagnosis. Moreover, childbearing has been reported to be an important issue for BOT survivors. ${ }^{3}$ Then, the issue of both conservative approach of ovarian tumors and alternative options to preserve childbearing potential becomes definitely important.

In the context, fertility preservation strategies arise with the aim of improving and maintaining the quality of life after cancer. Fertility-sparing surgery is a viable alternative for young women presenting BOT, since they have better prognosis when compared with other malignancies of the female gonad. ${ }^{4}$ However, oocytes are usually obtained by endovaginal puncture of the ovaries and the procedure is considered to be unsafe in the presence of adnexal tumors, given the risk of tumor capsule rupture and malignant cells spillage.

The feasibility of ex vivo egg collection has been demonstrated and it has been a seemingly successful strategy, according to case reports and series, especially involving the aspiration of immature eggs, then submitted to in vitro maturation (IVM) before vitrification..$^{5-10}$ As a matter of fact, in spite of being a patient-friendly intervention, reducing costs and avoiding the risk of ovarian hyperstimulation syndrome, the outcomes of IVM are not sufficiently good for its use as a technique of choice in assisted reproduction centers all over the world. Moreover, information on risks is still lacking, especially those related to genetic and epigenetic alterations. ${ }^{11}$

In a scenario where the reproductive outcomes from oocytes matured in vitro seem to be worse than those obtained from in vivo mature oocytes, ${ }^{11}$ ovarian stimulation for the ex vivo retrieval of mature eggs has been eventually performed and documented as a possible strategy. ${ }^{12-15}$ In the present paper, we report a case of ultrasound-guided retrieval of mature oocytes from stimulated ovaries after laparoscopic bilateral salpingo-oophorectomy, in a woman with bilateral borderline serous ovarian tumor.

\section{Case Report}

A 28-year-old married nulligravida, weighting $62.5 \mathrm{~kg}$ (body mass index $21.37 \mathrm{~kg} / \mathrm{m}^{2}$ ), was referred by her gynecologic
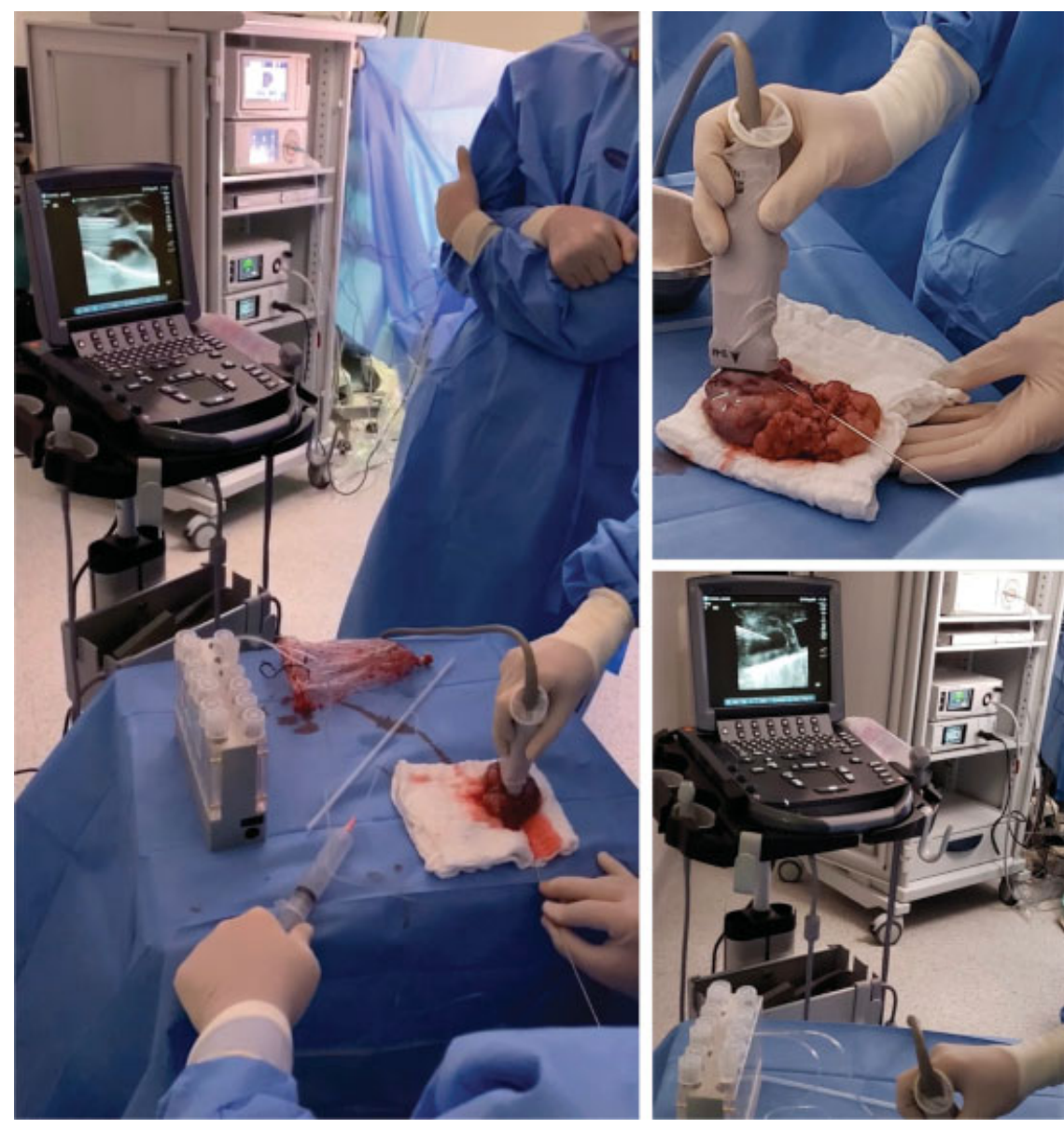

Fig. 1 Oocyte retrieval set. Up in the right, follicular aspiration with a standard aspiration single lumen needle, in a closed system connected directly to the tubes, under ultrasound guidance, using a 6-13 MHz linear probe applied directly to the specimen. Down in the right, sonographic view of the needle during guided follicular aspiration. 
oncologist on July 2019 for an emergency consultation regarding fertility preservation options, due to the finding of a bilateral adnexal mass, with the suspicion of being a borderline tumor. Indeed, there was an elevated chance of malignancy according to the criteria stablished by the International Ovarian Tumor Analysis group, ${ }^{16}$ based on the finding of an irregular solid tumor with capsular projections in the right ovary, and elevated tumor marker CA-125. Bilateral salpingo-oophorectomy was the proposed treatment.

Five days after the initial consultation (day 14 of the menstrual cycle), the patient received corifollitropin alfa (Elonva, Schering-Plough, Kenilworth, NJ, USA) in a subcutaneous (SC) single dose of $150 \mu \mathrm{g}$, for controlled ovarian stimulation (COS). Endovaginal ultrasound allowed the identification of 15 and 12 antral follicles $<10 \mathrm{~mm}$ in the right and left ovaries, respectively, and no dominant follicles were observed. To prevent premature Luteinizing Hormone ( $\mathrm{LH}$ ) surge, SC daily single doses of the GnRH antagonist ganirelix acetate (Orgalutran, ScheringPlough, Kenilworth, NJ, USA) were administered from day 6 onwards. From treatment day 8 to day 10 , ovarian stimulation was continued by SC daily doses of $250 \mathrm{IU}$ of recombinant follitropin (Puregon, Schering-Plough, Kenilworth, NJ, USA). A SC dose of $0.2 \mathrm{mg}$ of the gonadotropin-releasing hormone agonist triporelin acetate (Gonapeptyl Daily, Ferring, SaintPrex, Switzerland) was administered for final follicular maturation on treatment day 11 , when at least 11 follicles were expected to present with a mean diameter $\geq 16 \mathrm{~mm}$.

Surgery was scheduled according to the ovarian response to gonadotropic stimulation, and the patient was conducted to the operating room 36 hours after the ovulatory trigger. Bilateral salpingo-oophorectomy was proceeded by laparoscopy and both gonads were placed in plastic endobags for cavity protection, following the oncological procedure to avoid the dissemination of the disease. Extraction, then, was performed through a $5 \mathrm{~cm}$ vertical midline incision in the abdominal wall. The endobags containing the removed nonruptured ovaries were taken to the oocyte ex vivo retrieval set by the main surgeon, in the operating room, with a maximum ischemia time of 6 minutes.

In the oocyte retrieval set, the ovaries were placed over a sterile surgical cloth at room temperature. Oocyte retrieval was performed $\sim 37$ hours after the ovulatory trigger, with a standard aspiration single lumen needle (Wallace 17G Oocyte
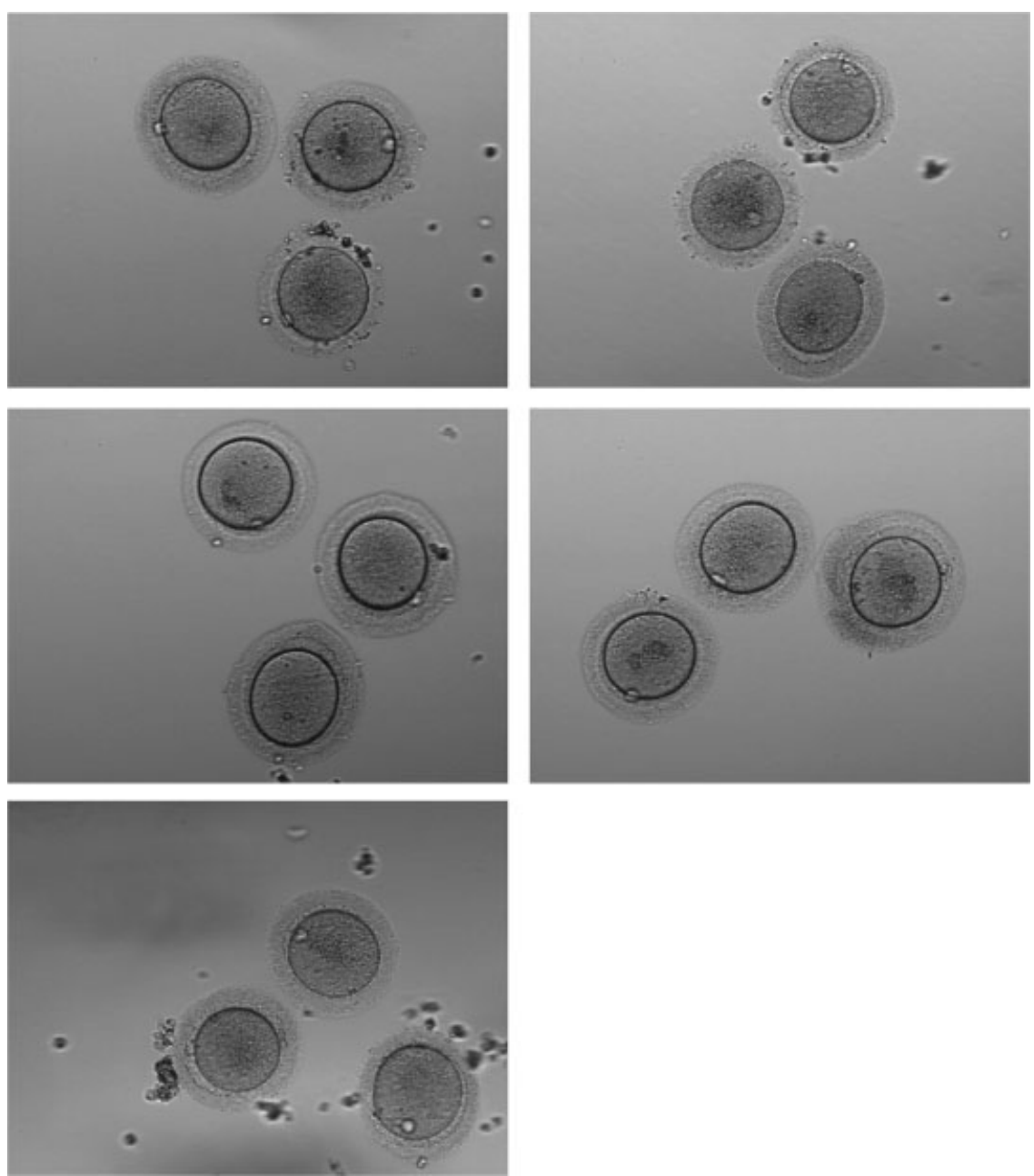

Fig. 2 Photomicrograph, 200x, of the mature oocytes which were vitrified. 

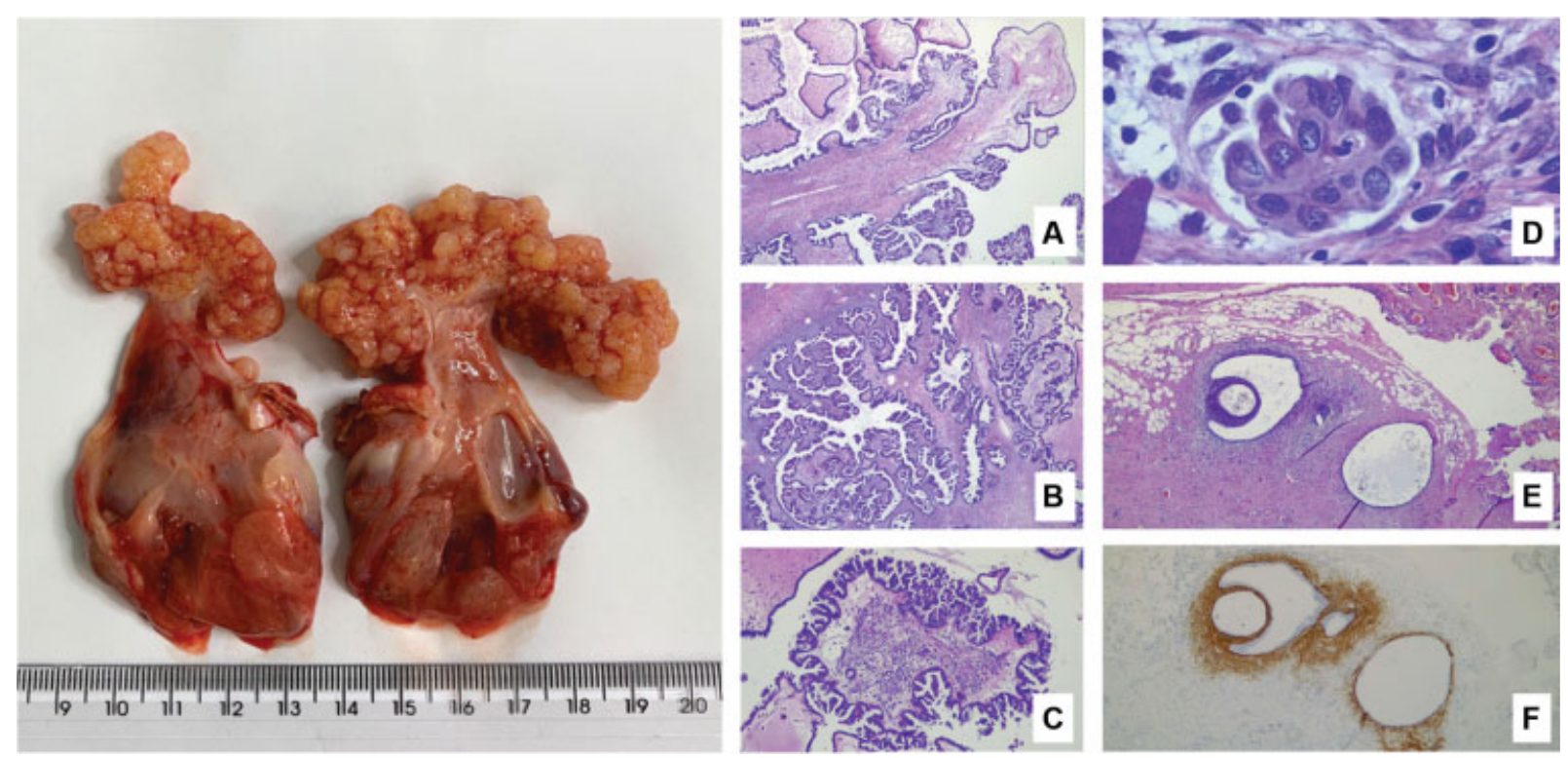

Fig. 3 Macroscopic external view of the tumor in both ovaries. Photomicrographs, in hematoxycilin-eosin, are disposed as: (A) 40x, branched fibroconjunctive papillae covered by serous epithelium, sometimes forming micropapillae. (B) 40x, area of endophytic growth, with no evidence of stromal invasion. (C) 100x, area with micropapillae, measuring $<5.0 \mathrm{~mm}$ (which means that it is not a low-grade noninvasive serous carcinoma). (D) $800 \mathrm{x}$, microinvasion focus in stroma, $<5.0 \mathrm{~mm}$, consisting of terminally differentiated/senescent-looking epithelioid cells (no clinical repercussions). (E) $40 \mathrm{x}$, focus of peritoneal endometriosis containing glands and stroma. (F) Immunohistochemistry, CD 10 positive in stromal cells of the endometriosis focus.

Recovery Set $330 \mathrm{~mm}$; Smiths Medical International, UK), in a closed system connected directly to the tubes, which were placed in a preheated tube warmer (model TW37, Origio, Målov, Denmark). All enlarged follicles were punctured and aspirated under ultrasound guidance, using a 6-13 $\mathrm{MHz}$ linear probe applied directly to the specimens ( $\mathbf{- F i g . 1}$ ).

A total of 20 ovarian follicles were aspirated, filling ten $14 \mathrm{~mL}$ tubes with follicular fluids, which were transported in the tube warmer, placed in a thermal box, with the intention of simulating optimal temperature to the embryology laboratory. The journey from the hospital to the laboratory was of $\sim 9 \mathrm{~km}$, completed in $\sim 16$ minutes.

Sixteen cumulus complexes were obtained. Cumulus cells were removed with hyaluronidase $40 \mathrm{IU} / \mathrm{mL}$, yielding 12 metaphase II (mature) and 3 metaphase I (immature) oocytes, and 1 germinal vesicle. The 3 immature oocytes were matured in vitro, and the final 15 mature oocytes obtained (-Fig. 2) were vitrified, 2,5 hours after being yielded, using a modified oocyte vitrification method as previously described by Kuwayama. ${ }^{17}$

Of note, the entire procedure was performed using absolute sterile steps. The surgical staging procedure was completed by oncological surgeons, and after safety evaluation, the uterus was preserved. Final histopathology confirmed the diagnosis of bilateral serous borderline tumor on the surface of both ovaries with microinvasion of $0.2 \mathrm{~mm}$ (-Fig. 3), without tubal commitment. As an accidental finding, endometriosis implants were identified in the rectosigmoid and in the right uterosacral ligament, also confirmed by histopathology. Finally, the postoperative follow-up of CA-125 levels showed a decrease from 273 $\mathrm{U} / \mathrm{mL}$ in day 10 after surgery to $9.62 \mathrm{U} / \mathrm{mL}$ after 3 months, and $7.09 \mathrm{U} / \mathrm{mL}$ in the last mensuration, which was made 4 days before we finished this report.

\section{Discussion}

We report a case of ultrasound-guided ex vivo retrieval of mature oocytes for fertility preservation in a woman with bilateral borderline ovarian tumor, for whom conventional transvaginal follicular aspiration was deemed unsafe because of the increased risk of malignant cell spillage. To our knowledge, this is the first report of an ex vivo retrieval of mature oocytes in Brazil, and the second using standard ultrasound guidance in the international literature.

Conservative surgery with the intention of preserving the ability to conceive has been increasingly practiced in surgical gynecological oncology and is no longer limited to ovarian transposition before radiotherapy. Preservation of the pelvic anatomy is currently desirable for young women without constituted offspring, especially concerning the uterus, and, in many cases, at least the contralateral ovary. ${ }^{18,19}$ In the meantime, there is consensus on the recommendation of caution regarding conservative surgery for hormone-sensitive ovarian tumors, as well as for high-risk serous borderline tumors $^{20}$ and those in advanced stages. ${ }^{3}$

To date, the safety of fertility sparing approaches to different ovarian tumors in childbearing age patients really seems to be realistic. The recent meta-analysis of eight observational studies, comparing 2,223 women undergoing conservative surgery with 5,809 undergoing radical surgery did not find differences in overall survival and disease-free survival with either surgical techniques for stage 1 epithelial ovarian cancer. ${ }^{21}$ In the same way, observational studies that 
evaluated the prognosis of malignant ovarian germ cell tumors $^{22}$ suggested that fertility sparing surgery is a safe treatment option, regardless of tumor stage and histological type, and a recent encouraging French casuistic demonstrated the experience of live births in two thirds of the women submitted to conservative surgery for borderline ovarian tumors, some occurring after recurrence. ${ }^{23}$

As interventions to be added to the oncological approach with the aim to preserve female reproductive capacity, techniques of cryopreservation of oocytes, embryos, or even the ovarian cortex have been increasingly used worldwide. ${ }^{24-27}$ In oncological cases, cryopreservation of mature oocytes seems to be the most interesting option, mainly for single women, those who do not wish to use donor sperm, or have religious or ethical objections to embryo freezing. ${ }^{26,28}$ Fortunately, pregnancy rates from in vitro fertilization of frozen eggs are very close to those seen with fresh eggs nowadays. ${ }^{29}$

It is noteworthy, however, that oocyte recovery is conventionally performed by follicular puncture through the vaginal fornix and, therefore, carrying the risk of rupture of the tumor capsule and tumor cells spillage, then changing the prognosis of the disease. Ex vivo recovery of oocytes eliminates that risk of peritoneal dissemination and the literature on the subject has been built from reports and case series. Conversely, oftentimes the puncture of oophorectomized specimens is proceeded without any stimulation, obtaining immature oocytes to be subsequently matured in vitro., $5,8,10$ As an example, in the series of 34 cases published by Segers et al, ${ }^{9}$ ex vivo recovery of immature oocytes resulted in obtaining mature oocytes in vitro or embryos available for cryopreservation in $79 \%$ of women, with an overall maturation rate of 36\% after IVM.

In spite of being a widely studied technique, IVM has not reached the status of a routine or widely used technique, since outcomes are far below expectations. ${ }^{11}$ For this reason, developing protocols and techniques that allow the capture of in vivo matured oocytes means a great advance for fertility preservation in women with ovarian malignancies.

To date, there are four case reports of ex vivo retrieval of mature oocytes after ovarian stimulation by exogenous gonadotropins in the literature. ${ }^{12-15}$ Fatemi et $^{1}{ }^{12}$ and Bocca et al ${ }^{13}$ were pioneers in the idea, both reporting the intervention occurring in women $<30$ years old, and obtaining satisfactory

Table 1 Summary of fertility preservation case reports using ex vivo retrieval of mature oocytes in ovarian tumors

\begin{tabular}{|c|c|c|c|c|c|c|c|c|}
\hline Reference & Age & $\begin{array}{l}\text { Marital status; } \\
\text { parity; brief } \\
\text { medical history }\end{array}$ & $\cos$ & Surgery type & Pathology & $\begin{array}{l}\text { US guidance } \\
\text { (yes/no) }\end{array}$ & $\begin{array}{l}\text { Total mature } \\
\text { oocytes } \\
\text { yielded }\end{array}$ & $\begin{array}{l}\text { Total } \\
\text { in vitro } \\
\text { matured } \\
\text { oocytes }\end{array}$ \\
\hline $\begin{array}{l}\text { Fatemi et al } \\
(2011)^{12}\end{array}$ & 27 & $\begin{array}{l}\text { Not mentioned; } \\
\text { nulliparous; previous } \\
\text { infertility reported; } \\
\text { previous laparoscopic } \\
\text { left salpingo- } \\
\text { oophorectomy, } \\
\text { papillary serous } \\
\text { adenocarcinoma; } \\
\text { ovarian reserve not } \\
\text { mentioned }\end{array}$ & $\begin{array}{l}\text { rFSH } 200 \mathrm{IU} / \text { day; ganirelix } \\
\text { acetate, } 0,25 \text { mg/day, } \\
\text { from day } 6 ; \text { maturation } \\
\text { trigger with urinary hCG } \\
10,000 \mathrm{IU}\end{array}$ & Laparotomy & $\begin{array}{l}\text { Papillary serous } \\
\text { adenocarcinoma } \\
\text { (recurrence) }\end{array}$ & No & $13^{\dagger}$ & 0 \\
\hline $\begin{array}{l}\text { Bocca et al } \\
(2011)^{13}\end{array}$ & 25 & $\begin{array}{l}\text { Single; nulliparous; } \\
\text { previous } \\
\text { laparoscopic left } \\
\text { salpingo- } \\
\text { oophorectomy, } \\
\text { serous borderline } \\
\text { ovarian tumor; } \\
\text { AFC } \sim 10\end{array}$ & $\begin{array}{l}\text { rFSH } 200 \mathrm{IU} / \text { day; ganirelix } \\
\text { acetate, } 0,25 \mathrm{mg} / \text { day, } \\
\text { from day } 7 \text { to day } 10 ; \\
\text { maturation trigger with } \\
\text { rhCG } 250 \mu \mathrm{g} \text { on day } 10\end{array}$ & $\begin{array}{l}\text { Laparoscopy, } \\
\sim 34-35 \text { hours } \\
\text { after maturation } \\
\text { trigger }{ }^{\ddagger}\end{array}$ & $\begin{array}{l}\text { Serous } \\
\text { borderline tumor }\end{array}$ & No & 14 & 0 \\
\hline $\begin{array}{l}\text { Pereira et al } \\
(2017)^{14}\end{array}$ & 37 & $\begin{array}{l}\text { Single; nulliparous; } \\
\mathrm{AFC} \sim 14\end{array}$ & $\begin{array}{l}\mathrm{rFSH} \\
300 \mathrm{IU} / \text { day }+ \text { hpHMG } \\
150 \mathrm{IU} / \text { day + letrozol } \\
5 \mathrm{mg} / \text { day; rFSH reduced to } \\
150 \mathrm{IU} / \text { day from day } 8 \text { to } \\
\text { day } 11 ; \text { ganirelix acetate, } \\
0,25 \mathrm{mg} / \text { day; maturation } \\
\text { trigger with rhCG } 250 \mathrm{\mu g} \text { on } \\
\text { day } 12\end{array}$ & $\begin{array}{l}\text { Laparotomy, } \\
\sim 34 \text { hours after } \\
\text { maturation } \\
\text { trigger }\end{array}$ & Not mentioned & No & 7 & 0 \\
\hline $\begin{array}{l}\text { de la Blanca } \\
\text { et al }(2018)^{15}\end{array}$ & 31 & $\begin{array}{l}\text { Single; nulliparous; } \\
\text { previous } \\
\text { laparoscopic left } \\
\text { salpingo- } \\
\text { oophorectomy, } \\
\text { mature teratoma; } \\
\text { AFC unfeasible, } \\
\text { AMH } 1.1 \mathrm{ng} / \mathrm{mL}\end{array}$ & $\begin{array}{l}\text { Chorifollitropin } \alpha 150 \mu \mathrm{g} \text {, } \\
\mathrm{rFSH} \\
200 \mathrm{IU} / \text { day from day } 8 \text { to } \\
\text { day } 9 \text {; ganirelix acetate, } \\
0,25 \mathrm{mg} / \text { day, from day } 6 \\
\text { to day } 10 ; \text { maturation } \\
\text { trigger with rhCG } 250 \mu \mathrm{g} \\
\text { on day } 10\end{array}$ & $\begin{array}{l}\text { Laparoscopy, } \\
\sim 35 \text { hours after } \\
\text { maturation } \\
\text { trigger }\end{array}$ & Struma ovarii & Yes & 5 & 0 \\
\hline
\end{tabular}

Abbreviations: AFC, Antral Follicle Count; AMH, Anti-Müllerian Hormone; COS, Controlled Ovarian hyperStimulation; hCG, Human Chorionic Gonadotropin; hpHMG, highly purified Menotropin; rhCG, recombinant Human Chorionic Gonadotropin; rFSH, recombinant Follicle Stimulating Hormone.

†Intracytoplasmic sperm injection was proceeded, and 7 top quality zygotes were vitrified.

‡Information obtained with the main author, Silvina Bocca, by e-mail, on May 6, 2020. 
amounts of mature oocytes, even aspirating the follicles identified by the external view. However, Pereira et $\mathrm{ll}^{14}$ recognized a technical limitation of the extracorporeal uptake of mature oocytes without ultrasound guidance, and the lack of this approach may be the reason for the small amount of gametes recovered, even though this was similar or superior to the number of oocytes obtained after ex vivo recovery of immature oocytes in published studies that included young women. 8,10

De la Blanca et $\mathrm{al}^{15}$ were the first to use ultrasound guidance directly applied to the specimens; an endovaginal probe was used to facilitate access to the follicles. Unfortunately, the number of mature eggs retrieved was not exactly satisfactory, especially considering that the patient was 31 years old and the ovarian reserve seemed to be normal. The reports describing the preservation of mature oocytes obtained by ex vivo capture are summarized in -Table 1.

We believe that the use of a $6-13 \mathrm{MHz}$ linear probe for ultrasound guidance to ovarian follicles aspiration helped us to achieve what we considered an excellent number of vitrified mature eggs. Also, it seems that we are the first to use IVM as an additional intervention, resulting in the highest number of mature vitrified oocytes for women with BOT ever published.

Of note, ovarian stimulation has not been associated with recurrence of ovarian malignancies to date, ${ }^{30}$ even in women with a high-risk Breast Cancer Gene (BRCA) mutation. ${ }^{31}$ Moreover, reports of live births following in vitro fertilization (IVF) after fertility-sparing surgery in patients with ovarian tumors suggest that pregnancy outcomes may be even better for them than those observed for infertile women, and that assisted reproductive techniques have no negative impact on the prognosis of cancer. ${ }^{32}$

\section{Conclusion}

In conclusion, our report emphasizes the viability of ex vivo mature oocyte retrieval after controlled ovarian stimulation for those with high risk of malignant dissemination by the conventional vaginal approach. Also, it reinforces the benefit of using ultrasound guidance for the access to ovarian follicles, which can be an important additive to achieve the best possible result.

\section{Conflict of Interests}

The authors have no conflict of interests to declare.

\section{References}

1 Yoshida A, Tavares BVG, Sarian LO, Andrade LALA, Derchain SF. Clinical features and management of women with borderline ovarian tumors in a single center in Brazil. Rev Bras Ginecol Obstet. 2019;41(03):176-182. Doi: 10.1055/s-0039-1683415

2 Schuurman MS, Timmermans M, van Gorp T, Van de Vijver KK, Kruitwagen RFPM, Lemmens VEPP, van der Aa MA. Trends in incidence, treatment and survival of borderline ovarian tumors in the Netherlands: a nationwide analysis. Acta Oncol. 2019;58(07): 983-989. Doi: 10.1080/0284186X.2019.1619935
3 Plett H, Harter P, Ataseven B, Heitz F, Prader S, Schneider S. Fertility-sparing surgery and reproductive-outcomes in patients with borderline ovarian tumors. Gynecol Oncol. 2020;157(02): 411-417. Doi: 10.1016/j.ygyno.2020.02.007

4 Candotti G, Peiretti M, Mangili G, Bergamini A, Candiani M, Cioffi $\mathrm{R}$, et al. What women want: Fertility sparing surgery in Borderline ovarian tumours patients and pregnancy outcome. Eur J Surg Oncol. 2020;46(05):888-892. Doi: 10.1016/j.ejso.2019.11.001

5 Revel A, Safran A, Benshushan A, Shushan A, Laufer N, Simon A. In vitro maturation and fertilization of oocytes from an intact ovary of a surgically treated patient with endometrial carcinoma: case report. Hum Reprod. 2004;19(07):1608-1611. Doi: 10.1093/ humrep/deh241

6 Huang JY, Buckett WM, Gilbert L, Tan SL, Chian RC. Retrieval of immature oocytes followed by in vitro maturation and vitrification: a case report on a new strategy of fertility preservation in women with borderline ovarian malignancy. Gynecol Oncol. 2007;105(02):542-544. Doi: 10.1016/j.ygyno.2007.01.036

7 Fadini R, Dal Canto M, Mignini Renzini M, Milani R, Fruscio R, Cantù MG, et al. Embryo transfer following in vitro maturation and cryopreservation of oocytes recovered from antral follicles during conservative surgery for ovarian cancer. J Assist Reprod Genet. 2012;29(08):779-781. Doi: 10.1007/s10815-012-9768-0

8 Prasath EB, Chan ML, Wong WH, Lim CJW, Tharmalingam MD, Hendricks $M$, et al. First pregnancy and live birth resulting from cryopreserved embryos obtained from in vitro matured oocytes after oophorectomy in an ovarian cancer patient. Hum Reprod. 2014;29(02):276-278. Doi: 10.1093/humrep/det420

9 Segers I, Mateizel I, Van Moer E, Smitz J, Tournaye H, Verheyen G, De Vos M. In vitro maturation (IVM) of oocytes recovered from ovariectomy specimens in the laboratory: a promising "ex vivo" method of oocyte cryopreservation resulting in the first report of an ongoing pregnancy in Europe. J Assist Reprod Genet. 2015;32 (08):1221-1231. Doi: 10.1007/s10815-015-0528-9

10 Park CW, Lee SH, Yang KM, Lee IH, Lim KT, Lee KH, Kim TJ. Cryopreservation of in vitro matured oocytes after ex vivo oocyte retrieval from gynecologic cancer patients undergoing radical surgery. Clin Exp Reprod Med. 2016;43(02):119-125. Doi: 10.5653/cerm.2016.43.2.119

11 Lu C, Zhang Y, Zheng X, Song X, Yang R, Yan J, et al. Current perspectives on in vitro maturation and its effects on oocyte genetic and epigenetic profiles. Sci China Life Sci. 2018;61(06): 633-643. Doi: 10.1007/s11427-017-9280-4

12 Fatemi HM, Kyrou D, Al-Azemi M, Stoop D, de Sutter P, Bourgain C, Devroey P. Ex-vivo oocyte retrieval for fertility preservation. Fertil Steril. 2011;95(05):1787.e15-1787.e17. Doi: 10.1016/j.fertnstert.2010.11.023

13 Bocca S, Dedmond D, Jones E, Stadtmauer L, Oehninger S. Successful extracorporeal mature oocyte harvesting after laparoscopic oophorectomy following controlled ovarian hyperstimulation for the purpose of fertility preservation in a patient with borderline ovarian tumor. J Assist Reprod Genet. 2011;28(09):771-772. Doi: 10.1007/s10815-011-9596-7

14 Pereira N, Hubschmann AG, Lekovich JP, Schattman GL, Rosenwaks Z. Ex vivo retrieval and cryopreservation of oocytes from oophorectomized specimens for fertility preservation in a BRCA1 mutation carrier with ovarian cancer. Fertil Steril. 2017;108(02): 357-360. Doi: 10.1016/j.fertnstert.2017.05.025

15 de la Blanca EP, Fernandez-Perez MF, Martin-Diaz EDM, Lozano M, Garcia-Sanchez M, Monedero C. Ultrasound-guided ex-vivo retrieval of mature oocytes for fertility preservation during laparoscopic oophorectomy: a case report.J Reprod Infertil. 2018;19(03):174-181

16 Timmerman D, Valentin L, Bourne TH, Collins WP, Verrelst H, Vergote IInternational Ovarian Tumor Analysis (IOTA) Group. Terms, definitions and measurements to describe the sonographic features of adnexal tumors: a consensus opinion from the International Ovarian Tumor Analysis (IOTA) Group. Ultrasound 
Obstet Gynecol. 2000;16(05):500-505. Doi: 10.1046/j.14690705.2000.00287.x

17 Kuwayama M. Highly efficient vitrification for cryopreservation of human oocytes and embryos: the Cryotop method. Theriogenology. 2007;67(01):73-80. Doi: 10.1016/j.theriogenology.2006.09.014

18 Mandelbaum RS, Blake EA, Machida H, Grubbs BH, Roman LD, Matsuo K. Utero-ovarian preservation and overall survival of young women with early-stage borderline ovarian tumors. Arch Gynecol Obstet. 2019;299(06):1651-1658. Doi: 10.1007/s00404019-05121-Z

19 Bourdel N, Huchon C, Cendos AW, Azaïs H, Bendifallah S, Bolze PA, et al. Tumeurs frontières de l'ovaire. Recommandations pour la pratique clinique du CNGOF - Texte court. Gynécol Obstét Fertil Sénol. 2020;48(03):223-235. Doi: 10.1016/j.gofs.2020.01.022

20 Rousset-Jablonski C, Selle F, Adda-Herzog E, Planchamp F, Selleret L, Pomel C, et al. Fertility preservation, contraception and menopause hormone therapy in women treated for rare ovarian tumours: guidelines from the French national network dedicated to rare gynaecological cancers. Eur J Cancer. 2019;116:35-44. Doi: 10.1016/j.ejca.2019.04.018

21 Liu D, Cai J, Gao A, Wang Z, Cai L. Fertility sparing surgery vs radical surgery for epithelial ovarian cancer: a meta-analysis of overall survival and disease-free survival. BMC Cancer. 2020;20 (01):320. Doi: 10.1186/s12885-020-06828-y

22 Mikuš M, Benco N, Matak L, Planicić P, Ćoric M, Lovrić H, et al. Fertility-sparing surgery for patients with malignant ovarian germ cell tumors: 10 years of clinical experience from a tertiary referral center. Arch Gynecol Obstet. 2020;301(05):1227-1233. Doi: $10.1007 / \mathrm{s} 00404-020-05522-5$

23 Chevrot A, Pouget N, Bats AS, Huchon C, Guyon F, Chopin N, et al. Fertility and prognosis of borderline ovarian tumor after conservative management: Results of the multicentric OPTIBOT study by the GINECO \& TMRG group. Gynecol Oncol. 2020;157(01):29-35. Doi: 10.1016/j.ygyno.2019.12.046
24 Wright JD, Shah M, Mathew L, Burke WM, Culhane J, Goldman N, et al. Fertility preservation in young women with epithelial ovarian cancer. Cancer. 2009;115(18):4118-4126. Doi: 10.1002/cncr.24461

25 Rashedi AS, de Roo SF, Ataman LM, Edmonds ME, Silva AA, Scarella A, et al. Survey of fertility preservation options available to patients with cancer around the globe. J Glob Oncol. 2018; 4:1-16. Doi: 10.1200/JGO.2016.008144

26 Oktay K, Harvey BE, Loren AW. Fertility preservation in patients with cancer: ASCO Clinical Practice Guideline update summary. J Oncol Pract. 2018;14(06):381-385. Doi: 10.1200/JOP.18.00160

27 Practice Committee of the American Society for Reproductive Medicine. Electronic address: asrm@asrm.org. Fertility preservation in patients undergoing gonadotoxic therapy or gonadectomy: a committee opinion. Fertil Steril. 2019;112(06):1022-1033. Doi: $10.1016 /$ j.fertnstert.2019.09.013

28 Carvalho BR, Kliemchen J, Woodruff TK. Ethical, moral and other aspects related to fertility preservation in cancer patients.JBRA Assist Reprod. 2017;21(01):45-48. Doi: 10.5935/1518-0557.20170011

29 Cobo A, Garcia-Velasco JA, Domingo J, Remohí J, Pellicer A. Is vitrification of oocytes useful for fertility preservation for agerelated fertility decline and in cancer patients? Fertil Steril. 2013; 99(06):1485-1495. Doi: 10.1016/j.fertnstert.2013.02.050

30 Feichtinger M, Rodriguez-Wallberg KA. Fertility preservation in women with cervical, endometrial or ovarian cancers. Gynecol Oncol Res Pract. 2016;3:8. Doi: 10.1186/s40661-016-0029-2

31 Perri T, Lifshitz D, Sadetzki S, Oberman B, Meirow D, Ben-Baruch $G$, et al. Fertility treatments and invasive epithelial ovarian cancer risk in Jewish Israeli BRCA1 or BRCA2 mutation carriers. Fertil Steril. 2015;103(05):1305-1312. Doi: 10.1016/j.fertnstert.2015.02.011

32 Li S, Lin H, Xie Y, Jiao X, Qiu Q, Zhang Q. Live births after in vitro fertilization with fertility-sparing surgery for borderline ovarian tumors: a case series and literature review. Gynecol Obstet Invest. 2019;84(05):445-454. Doi: 10.1159/000497203 